\title{
Probing genetic control of swine responses to PRRSV infection: current progress of the PRRS host genetics consortium
}

Joan K Lunney ${ }^{1 *}$, Juan Pedro Steibel ${ }^{2}$, James M Reecy ${ }^{3}$, Eric Fritz ${ }^{3}$, Max F Rothschild ${ }^{3}$, Maureen Kerrigan ${ }^{4}$, B Trible $^{4}$, Raymond RR Rowland ${ }^{4}$

From International Symposium on Animal Genomics for Animal Health (AGAH 2010)

Paris, France. 31 May - 2 June 2010

\begin{abstract}
Background: Understanding the role of host genetics in resistance to porcine reproductive and respiratory syndrome virus (PRRSV) infection, and the effects of PRRS on pig health and related growth, are goals of the PRRS Host Genetics Consortium (PHGC).

Methods: The project uses a nursery pig model to assess pig resistance/susceptibility to primary PRRSV infection. To date, 6 groups of 200 crossbred pigs from high health farms were donated by commercial sources. After acclimation, the pigs were infected with PRRSV in a biosecure facility and followed for 42 days post infection (dpi). Blood samples were collected at 0, 4, 7, 10, 14, 21, 28, 35 and 42 dpi for serum and whole blood RNA gene expression analyses; weekly weights were recorded for growth traits. All data have been entered into the PHGC relational database. Genomic DNAs from all PHGC1-6 pigs were prepared and genotyped with the Porcine SNP60 SNPchip.

Results: Results have affirmed that all challenged pigs become PRRSV infected with peak viremia being observed between 4-21 dpi. Multivariate statistical analyses of viral load and weight data have identified PHGC pigs in different virus/weight categories. Sera are now being compared for factors involved in recovery from infection, including speed of response and levels of immune cytokines. Genome-wide association studies (GWAS) are underway to identify genes and chromosomal locations that identify PRRS resistant/susceptible pigs and pigs able to maintain growth while infected with PRRSV.
\end{abstract}

Conclusions: Overall, the PHGC project will enable researchers to discover and verify important genotypes and phenotypes that predict resistance/susceptibility to PRRSV infection. The availability of PHGC samples provides a unique opportunity to continue to develop deeper phenotypes on every PRRSV infected pig.

\section{Introduction}

Porcine reproductive and respiratory syndrome virus (PRRSV), first identified in the United States in 1987, costs U.S. swine producers $>\$ 560$ million annually [1]. PRRSV-infected pigs are susceptible to pneumonia and growth losses; infected sows have increased rates of abortions, stillbirths, mummifications, and give birth to

\footnotetext{
* Correspondence: Joan.Lunney@ars.usda.gov

'Animal Parasitic Diseases Laboratory, BARC, ARS, USDA, Beltsville, MD 20705, USA

Full list of author information is available at the end of the article
}

weak piglets with chronic respiratory problems. It can take weeks, even months, for pigs to clear this RNA virus, which evolves and adapts quickly to new environmental challenges such as vaccines and medications [2]. Reports of highly virulent PRRSV variants that have spread throughout China and into Vietnam highlight the importance of developing effective interventions to prevent PRRSV pathology, mortality and production losses [3-5].

Research has indicated that there are genetic components involved in determining how effective each pig 
will be in responding to and clearing PRRSV infection [6-17]. As discussed during the 2010 Animal Genomics for Animal Health International Symposium deep phenotypes are required for identifying the genes and pathways that are responsible for genetic control of PRRSV infection responses. Large numbers of animals and a resulting broad sample set is required to probe the numerous parameters involved. Such an effort requires that several entities pool their funding and scientific resources. In the US, the PRRS Host Genetics Consortium (PHGC) has been developed to coordinate a PRRS host genetics and resistance project. The objectives for the PHGC are to: 1) Use genotyping and phenotyping tools to determine if there are host genes that control resistance/susceptibility to PRRSV infection; 2) Verify genetic variation in response to PRRSV, via improved health, survivability and growth; and 3) Identify relative importance of different phenotypic traits, and their heritability, that predict response to PRRSV infection.

\section{Methods}

\section{PHGC Planning}

A large project such as the PHGC requires careful planning and commitments from diverse groups. The PHGC was developed at three one-day US National Pork Board meetings $(15 / 12 / 05 ; 23 / 2 / 06 ; 9 / 5 / 07)$ with further input from PRRS CAP and NC229 disease researchers, NC1037/NRSP8 genome researchers, members of the NPB Swine Health and Animal Science Committees, veterinarians and the American Association of Swine Veterinarians, producers, and commercial partners representing breeders, animal health, feed, and diagnostic companies. The final plan is a result of those detailed discussions.

\section{Pig sources}

All tests have been performed on commercial pigs from high health farms with donation of swine genetic materials as part of the Consortium. For each trial one company was requested to provide 200 pigs at weaning from PRRSV negative (PRRSV-), Mycoplasma hyopneumoniae-, and swine influenza virus- farms, and if possible from porcine circovirus type 2 (PCV2) free farms. Pigs could be from vaccinated sows since maternal antibody prevents them from becoming infected with PCV2. The source populations were crossbred commercial pigs (Genus/PIC USA; Newsham Choice Genetics; Fast Genetics; Genetiporc, Inc.; Genesus Genetics) with complete parentage and pedigree records. Since SNP chips are used for genotyping there was a decreased need for extensive family structure. There was no preselection of sires for disease traits. Pigs ( 200/trial) were transported to the biosecure Kansas State University (KSU) testing facility at weaning. All pig experiments were initiated after approval by KSU IACUC and IBC institutional committees. After arrival pigs were treated with broad spectrum antibiotics for 1 week, to prevent expression of other organisms.

\section{Infection and phenotypic tests}

After the 7 day acclimation period, pigs were challenged intranasally/orally with PRRSV isolate NVSL 97-7985 [18] and followed for 42 days post infection (dpi). Blood samples are collected at $-6,0,4,7,10,14,21,28,35,42$ dpi for a total of 10 bleeds. Both sera and ABI Tempus tubes for later RNA analyses were collected at all sampling times. All samples were aliquoted and stored at KSU and BARC. Pigs were weighed weekly for growth data. Pigs were killed at $42 \mathrm{dpi}$ and tonsils collected for viral persistence and ears for genomic DNA. If there are pig deaths during the study, dead pigs are sent for full workup at the KSU Diagnostic Lab.

\section{Consortium database}

The Consortium relational database http://www.animalgenome.org/lunney/index.php is the secure data repository for all pig data including parentage information, location and availability of all samples collected on each pig, results of all assays performed on each sample (phenotypic and genotypic information). The database resides on computers located at Iowa State University, which are supported by NRSP8 Bioinformatics funds. All data collected through the project will be available to project members prior to publication and then to general public after original publication. Access to samples and to accumulated data stored in the secure PHGC Database is open to members who contribute materials or data. [Access to PHGC Database is monitored by the USDA ARS maintained Cooperative Research and Development Agreement (CRADA) Material Transfer Agreement (MTA).]

\section{Results and discussion}

Results have affirmed that all challenged pigs become PRRSV infected with peak viremia from 4-21 dpi (Rowland et al., manuscript in preparation). The PHGC results revealed the appearance of stratified subpopulations of PRRS resistant/ susceptible pigs, which exhibited wide variations in virus load and growth performance; examples of such anti-viral responses are shown in Figure 1. The greatest impact of PRRSV infection was on weight, with only about $30 \%$ of infected pigs in the same weight class as the reference control pigs (pigs from the same litters kept uninfected and weighed for the same 42 days). Plotting virus load versus average daily weight gain (ADWG) showed little correlation between growth and virus load. Multivariate statistical analyses of viral load and weight data have 


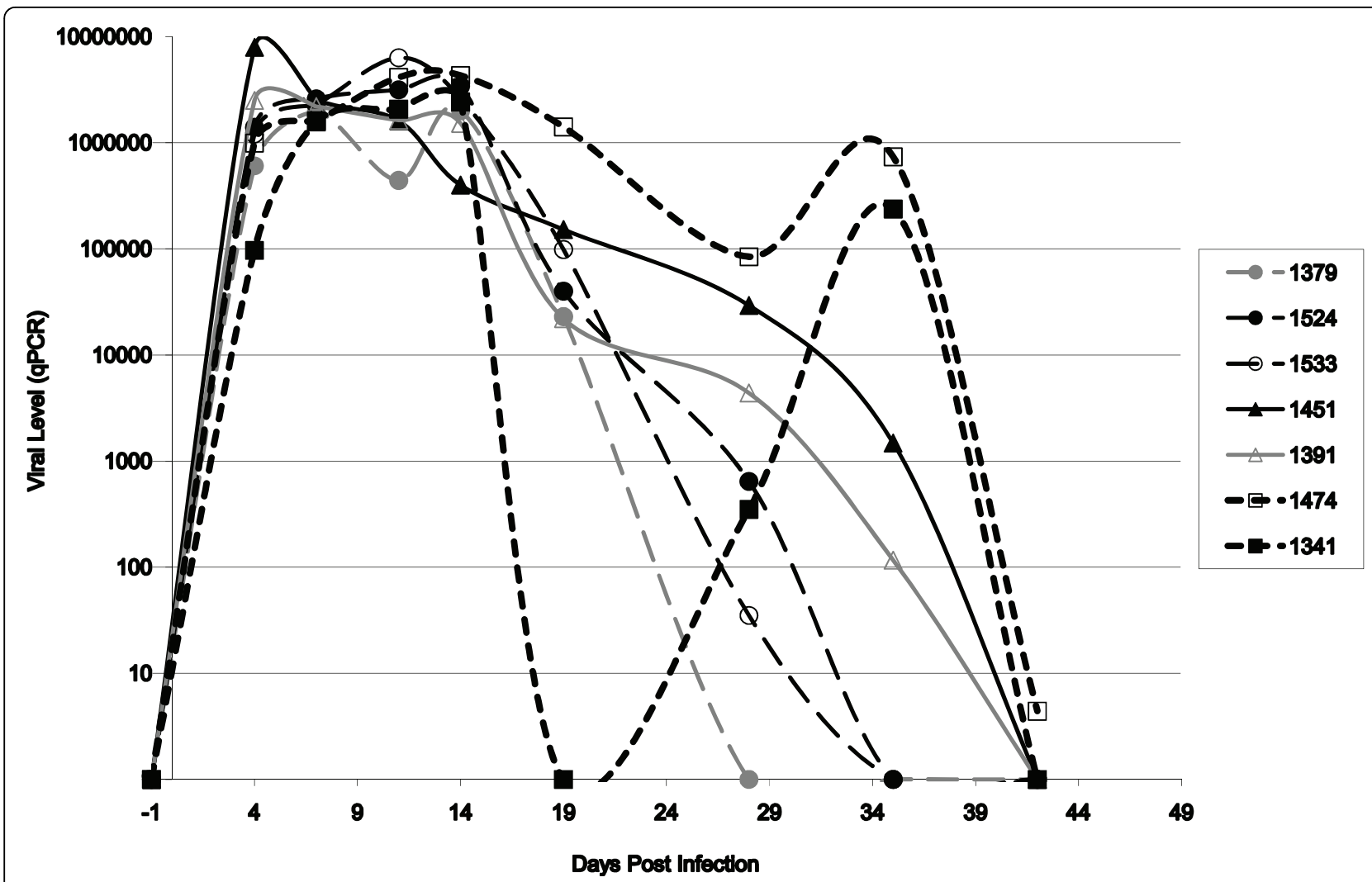

Figure 1 Different anti-viral reponses associated with PRRS resistance/susceptibility. PHGC pigs exhibited different anti-PRRSV infection responses as reflected in the serum viral levels after challenge. Circles, solid squares/long dashed lines - resistant pigs (1341, 1379, 1524, 1533); Triangles/solid lines= susceptible pigs $(1451,1391)$; Squares/short dashed line = pigs with virus reactivation $(1341,1474)$.

categorized PHGC pigs into 4 extreme categories including the most desirable, PRRS resistant low virus/ high weight gain $(\mathrm{Lv} / \mathrm{Hg})$ pigs, the worst, PRRS susceptible high virus/ low weight gain (Hv/Lg) pigs, the PRRS tolerant, high virus/high weight gain $(\mathrm{Hv} / \mathrm{Hg})$ pigs, and the less thrifty, low virus/low weight gain ( Lv/Lg) pigs. This statistical categorization of pigs from each PHGC trial provides a critical basis for selecting pigs and samples for detailed analyses of processes that control transcriptional and proteomic responses to PRRSV infection, as outlined in Table 1.

Sera are now being compared for factors involved in recovery from infection, including speed of anti-viral responses and levels of immune cytokines. Selected whole blood RNA samples are being compared for gene expression using the Pigoligoarrays [19]. In Table 1 are listed the PRRS resistance/susceptibility phenotypic traits currently being tested as well as those that could be collected with additional tests for deeper phenotypic information if additional funding becomes available. This continued phenotyping is possible because of the extensive PHGC planning, detailed sample inventory at $\mathrm{KSU}$ and BARC, and coordinated PHGC database.
Genomic DNA samples from all trial 1-6 PHGC pigs have already been prepared and genotyped with the Porcine SNP60 SNPchip; a grant submission for the last genotypes and RNA-seq analyses is under review. Genome-wide association studies (GWAS) are now underway to identify alleles and chromosomal regions that are associated with anti-PRRSV infection responses. Overall, the PHGC project will enable researchers to verify important genotypes and phenotypes that predict resistance/susceptibility to PRRSV infection.

\section{Conclusion}

The expected outcomes of the PRRS Host Genetics Consortium are to: 1) Define genomic regions, SNP alleles, or candidate genes [and source pig genetics] which are correlated with PRRS resistance/susceptibility quantitative trait loci (QTL); 2) Use these QTL to develop selection procedures to lower the effects and persistence of PRRSV virus in pigs; 3) Determine why [some] pigs stay healthy despite PRRSV infection; 4) Utilize information gained to help uncover unique PRRSV resistance mechanisms and virus-host interactions, thus highlighting alternate vaccine and therapeutic 
Table 1 PRRS resistance/susceptibility traits for genome wide association studies (GWAS) and gene expression pathway analyses

\begin{tabular}{|c|c|c|c|}
\hline Sample & Trait & Current phenotypic information & Potential phenotypic information \\
\hline $\begin{array}{l}\text { Blood serum } \\
\text { [collected at -6, 0, 4, 7, 10, 14, 21, } \\
28,35,42 \text { dpi] }\end{array}$ & Virus levels & $\begin{array}{l}\text { PRRS Viral qPCR } \\
\text { [4 dpi virus level, } 7 \text { dpi virus level, 0-19/21 dpi } \\
\text { virus level (= AUC, area under curve); } 28 \text { dpi virus } \\
\text { level] }\end{array}$ & $\begin{array}{l}\text { PRRSV type } 1 \text { and } 2 \\
\text { Virus sequence, especially during } \\
\text { reactivation } \\
\text { Presence of other viruses }\end{array}$ \\
\hline Blood serum & $\begin{array}{l}\text { Antibody (Ab) } \\
\text { levels }\end{array}$ & IDEXX PRRSV Ab titer & $\begin{array}{l}\text { PRRSV Serum Neutralizing Abs } \\
\text { Decay of maternal anti-PCV2 Ab } \\
\text { Ab to other microbes }\end{array}$ \\
\hline Blood serum & $\begin{array}{l}\text { Immune } \\
\text { Protein levels }\end{array}$ & $\begin{array}{l}\text { Interleukin-8 (IL-8), Interferon- } \gamma \text { (IFN- } \gamma \text { ) } \\
\text { Selected Luminex bead assays for } 8 \text { cytokines }\end{array}$ & $\begin{array}{l}\text { More Luminex bead assays for multiple } \\
\text { cytokines, chemokines } \\
\text { Broad proteomic analyses }\end{array}$ \\
\hline $\begin{array}{l}\text { Blood RNA } \\
\text { (ABI Tempus tubes for RNA } \\
\text { collected at } 0,4,7,10,14,21,28 \text {, } \\
35,42 \text { dpi) }\end{array}$ & $\begin{array}{l}\text { Blood gene } \\
\text { expression }\end{array}$ & $\begin{array}{l}\text { Microarray (Pigoligoarray) based gene expression } \\
\text { QPCR for selected gene expression } \\
\text { Identification of "classifier genes" for PRRS } \\
\text { resistance }\end{array}$ & $\begin{array}{l}\text { next generation sequencing analyses (RNA- } \\
\text { seq) } \\
\text { Alternate splicing events } \\
\text { Bioinformatic analysis of virus/host } \\
\text { correlated gene expression } \\
\text { Identify eQTL }\end{array}$ \\
\hline Growing pig [during infection] & $\begin{array}{l}\text { Weight gain } \\
(\mathrm{kg})\end{array}$ & $\begin{array}{l}\text { Weight gain [Overall 0-42 dpi; Weight gain at } \\
\text { peak virus replication] }\end{array}$ & $\begin{array}{l}\text { New trials with growth to market weight } \\
\text { and extensive growth and pork quality } \\
\text { analyses }\end{array}$ \\
\hline Ear tissue & Genomic DNA & $\begin{array}{l}\text { SNP genotyping (Illumina PorcineSNP60 } \\
\text { Genotyping BeadChip) } \\
\text { Targeted SNPs } \\
\text { GWAS analyses }\end{array}$ & $\begin{array}{l}\text { Broader SNP analyses } \\
\text { More Targeted SNPs, e.g., specific regions } \\
\text { or candidate genes } \\
\text { More extensive GWAS analyses including } \\
\text { eQTL and Ref-seq data }\end{array}$ \\
\hline Tonsils [at $42 \mathrm{dpi}$ ] & $\begin{array}{l}\text { Mucosal } \\
\text { tissue; virus } \\
\text { reservoir }\end{array}$ & None & $\begin{array}{l}\text { PRRSV levels at } 42 \text { dpi - PRRSV persistence } \\
\text { Gene expression with persistent virus }\end{array}$ \\
\hline $\begin{array}{l}\text { Oral fluids } \\
\text { [pen samples] }\end{array}$ & Virus levels & PRRSV levels & $\begin{array}{l}\text { PRRSV type } 1 \text { and } 2 \\
\text { Virus sequence, especially during } \\
\text { reactivation } \\
\text { Presence of other viruses }\end{array}$ \\
\hline Oral fluids & $\begin{array}{l}\text { Antibody (Ab) } \\
\text { levels }\end{array}$ & IDEXX PRRSV Ab titer & $\begin{array}{l}\text { PRRSV Serum Neutralizing Abs } \\
\text { Decay of maternal anti-PCV2 Ab } \\
\text { Ab to other microbes } \\
\text { Comparison of oral fluid versus serum } \\
\text { responses }\end{array}$ \\
\hline Oral fluids & $\begin{array}{l}\text { Immune } \\
\text { Protein levels }\end{array}$ & Selected Luminex bead assay for cytokines & $\begin{array}{l}\text { More Luminex bead assays for multiple } \\
\text { cytokines, chemokines } \\
\text { Broad proteomic analyses }\end{array}$ \\
\hline
\end{tabular}

Sample usage plans for current phenotypic information and projected deeper phenotypic data possible with additional tests and funding.

approaches; and 5) Identify pigs with improved resistance not just to PRRS but to respiratory infections.

\section{List of abbreviations used}

Ab: Antibody; AUC: area under the curve; dpi: days post infection; GWAS: genome-wide association studies; QTL: quantitative trait loci; PCV2: porcine circovirus type 2; PRRSV: porcine reproductive and respiratory syndrome virus; PHGC: PRRS Host Genetics Consortium.

\section{Acknowledgements}

The PHGC has funding from the US National Pork Board (NPB) (\#07-233, \#09208, \#10-033 for PRRSV infection and \#09-244 for FMIA analyses of serum cytokines); PRRS CAP, USDA-NIFA Award \#2008-55620-19132 for SNP genotyping and GWAS analyses; and USDA NIFA AFRI Animal Genome \#2010-65205-20433 for gene expression analyses. In addition matching funds have come from the USDA sponsored National Research Support Project 8 (NRSP-8) Swine Genome and Bioinformatics Coordination programs, from several swine breeding companies, and from Hatch funds, Kansas State
University, lowa State University, and USDA ARS project 1254-32000-088 support.

This article has been published as part of BMC Proceedings Volume 5 Supplement 4, 2011: Proceedings of the International Symposium on Animal Genomics for Animal Health (AGAH 2010). The full contents of the supplement are available online at http://www.biomedcentral.com/1753$6561 / 5$ ? issue $=$ S4

\section{Author details}

${ }^{1}$ Animal Parasitic Diseases Laboratory, BARC, ARS, USDA, Beltsville, MD 20705, USA. ${ }^{2}$ Depts. Animal Science, and Fisheries and Wildlife, Michigan State Univ., East Lansing, MI 48824, USA. ${ }^{3}$ Dept. Animal Science, Center for Integrated Animal Genomics, lowa State Univ., Ames, IA 50011, USA. ${ }^{4}$ Dept. Diagnostic Medicine and Pathobiology, College of Veterinary Medicine, Kansas State Univ., Manhattan, KS 66506, USA

\section{Competing interests}

The authors declare that they have no competing interests.

Published: 3 June 2011 


\section{References}

1. Neumann EJ, Kliebenstein JB, Johnson CD, Mabry JW, Bush EJ, Seitzinger AH, Green AL, Zimmerman JJ: Assessment of the economic impact of porcine reproductive and respiratory syndrome on swine production in the United States. J Am Vet Med Assoc 2005, 227:385-92.

2. Mateu E, Diaz I: The challenge of PRRS immunology. Vet J 2008, 177:345-51.

3. Tian K, Yu X, Zhao T, Feng Y, Cao Z, Wang C, Hu Y, Chen X, Hu D, Tian X, Liu D, Zhang $S$, Deng $X$, Ding $Y$, Yang L, Zhang Y, Xiao H, Qiao M, Wang B, Hou L, Wang $X$, Yang $X$, Kang L, Sun M, Jin P, Wang S, Kitamura $Y$, Yan J, Gao GF: Emergence of fatal PRRSV variants: unparalleled outbreaks of atypical PRRS in China and molecular dissection of the unique hallmark. PLOS ONE 2007, 2:e526.

4. Wu J, Li J, Tian F, Ren S, Yu M, Chen J, Lan Z, Zhang X, Yoo D, Wang J: Genetic variation and pathogenicity of highly virulent porcine reproductive and respiratory syndrome virus emerging in China. Arch Virol 2009, 154:1589-97.

5. Li B, Fang L, Liu S, Zhao F, Jiang Y, He K, Chen H, Xiao S: The genomic diversity of Chinese porcine reproductive and respiratory syndrome virus isolates from 1996 to 2009. Vet Microbiol 2010, 146:226-237.

6. Halbur P, Rothschild M, Thacker B: Differences in susceptibility of Duroc, Hampshire, and Meishan pigs to infection with a high-virulence strain (VR2385) of porcine reproductive and respiratory syndrome virus (PRRSV). J. Anim. Breed. Genet 1998, 115:181-189.

7. Vincent AL, Thacker BJ, Halbur PG, Rothschild MF, Thacker EL: In vitro susceptibility of macrophages to porcine reproductive and respiratory syndrome virus varies between genetically diverse lines of pigs. Viral Immunol 2005, 18:506-12.

8. Vincent AL, Thacker BJ, Halbur PG, Rothschild MF, Thacker EL: An investigation of susceptibility to porcine reproductive and respiratory syndrome virus between two genetically diverse commercial lines of pigs. J Anim Sci 2006, 84:49-57.

9. Lewis CR, Ait-Ali T, Clapperton M, Archibald AL, Bishop S: Genetic perspectives on host responses to porcine reproductive and respiratory syndrome (PRRS). Viral Immunol 2007, 20:343-58.

10. Lewis CRG, Torremorell M, Bishop SC: Effects of Porcine Reproductive and Respiratory Syndrome (PRRS) virus infection on the performance of commercial sows and gilts of different parities and lines. I Swine Health and Production 2009, 17:140-147.

11. Lewis CR, Torremorell M, Galina-Pantoja L, Bishop SC: Genetic parameters for performance traits in commercial sows estimated before and after an outbreak of porcine reproductive and respiratory syndrome. J. Anim Sci 2009, 87:876-84.

12. Ait-Ali T, Wilson AD, Westcott DG, Clapperton $M$, Waterfall $M$, Mellencamp MA, Drew TW, Bishop SC, Archibald AL: Innate immune responses to replication of porcine reproductive and respiratory syndrome virus in isolated Swine alveolar macrophages. Viral Immunol 2007, 20:105-18.

13. Doeschl-Wilson AB, Kyriazakis I, Vincent A, Rothschild MF, Thacker E, GalinaPantoja L: Clinical and pathological responses of pigs from two genetically diverse commercial lines to porcine reproductive and respiratory syndrome virus infection. J Anim Sci 2009, 87:1638-47.

14. Petry DB, Holl JW, Weber JS, Doster AR, Osorio FA, Johnson RK: Biological responses to porcine respiratory and reproductive syndrome virus in pigs of two genetic populations. J Anim Sci 2005, 83:1494-502.

15. Petry DB, Lunney J, Boyd P, Kuhar D, Blankenship E, Johnson RK: Differential immunity in pigs with high and low responses to porcine reproductive and respiratory syndrome virus infection. J Anim Sci 2007, 85:2075-92.

16. Reiner $G$, Willems $H$, Pesch $S$, Ohlinger VF: Variation in resistance to the porcine reproductive and respiratory syndrome virus (PRRSV) in Pietrain and Miniature pigs. J Anim Breed Genet 2010, 127:100-106.

17. Lunney JK, Chen $\mathrm{H}$ : Genetic control of porcine reproductive and respiratory syndrome virus responses. Virus Research 2010, 154:161-169.

18. Osorio FA, Galeota JA, Nelson E, Brodersen B, Doster A, Wills R, Zuckermann F, Laegreid WW: Passive transfer of virus-specific antibodies confers protection against reproductive failure induced by a virulent strain of porcine reproductive and respiratory syndrome virus and establishes sterilizing immunity. Virology 2002, 302:9-20.
19. Steibel JP, Wysocki M, Lunney JK, Ramos AM, Hu ZL, Rothschild MF, Ernst CW: Assessment of the swine protein-annotated oligonucleotide microarray. Anim Genet 2009, 40:883-893.

doi:10.1186/1753-6561-5-S4-S30

Cite this article as: Lunney et al:: Probing genetic control of swine responses to PRRSV infection: current progress of the PRRS host genetics consortium. BMC Proceedings 2011 5(Suppl 4):S30.

\section{Submit your next manuscript to BioMed Central and take full advantage of:}

- Convenient online submission

- Thorough peer review

- No space constraints or color figure charges

- Immediate publication on acceptance

- Inclusion in PubMed, CAS, Scopus and Google Scholar

- Research which is freely available for redistribution

Submit your manuscript at www.biomedcentral.com/submit 